\title{
The Relationship between Teachers' Perceptions of Organizational Justice and Authentic Leadership and Their Levels of Organizational Happiness ${ }^{1}$
}

\author{
DOI: $10.26466 /$ opus. 877220
}

*

\author{
Hatice Demir* - Muhammed Zincirli ** \\ * Teacher, Ministry of Education \\ E-Mail: hatice.yes@hotmail.com \\ ORCID: $\underline{0000-0001-7784-3426}$ \\ ${ }^{* *}$ Asst. Prof, Firat University \\ E-Mail : mzincirli@firat.edu.tr \\ ORCID: $\quad \underline{0000-0003-0716-6794}$
}

\begin{abstract}
The purpose of this study is to determine the relationship between teachers' perceptions of organizational justice and authentic leadership and their organizational happiness levels. The research was carried out in survey model. The population of the study consists of teachers working in public schools in Elazig province center in the 2019-2020 academic year. The sample of the research was determined by quota sampling method, and the research was carried out by analyzing the data obtained from 436 teachers serving at various grades. Within the scope of the research, the data were collected with the Organizational Justice Scale (OJS), the Authentic Leadership Scale (ALS), the Organizational Happiness Scale (OHS) and the personal information form prepared by the researcher. The data obtained were analyzed with reliability, percentage, frequencies, $t$-test, Pearson Correlation Analysis and Multiple Regression Analysis. According to the findings obtained from the study, it was observed that teachers' organizational justice, authentic leadership and organizational happiness scores did not differ significantly according to their gender and marital status. According to the results of Pearson correlation analysis, there are positive and significant relationships between the organizational justice and authentic leadership perceptions of the participants and their organizational happiness levels. Finally, because of the multiple regression analysis, it was determined that the participants' perceptions of organizational justice and authentic leadership (relational transparency sub-dimension) significantly predicted their organizational happiness levels, and these two variables explained approximately $18 \%$ of the change in organizational happiness. According to these results, it can be said that organizational justice and authentic leadership behaviors play a role in teachers' organizational happiness levels.
\end{abstract}

Keywords: Organizational justice, authentic leadership, organizational happiness, teacher.

\footnotetext{
${ }^{1}$ This study was produced from Hatice Demir's master thesis accepted by Firat University Institute of Educational Sciences under the supervision of Muhammed Zincirli.
} 


\title{
Öğretmenlerin Örgütsel Adalet ve Otantik Liderlik Algıları ile Örgütsel Mutluluk Düzeyleri Arasındaki İlişki
}

\begin{abstract}
Öz
Bu çalışmanın amacl; öğretmenlerin örgütsel adalet ve otantik liderlik algiları ile örgütsel mutluluk düzeyleri arasındaki ilişkiyi tespit etmektir. Araştırmada tarama modeli kullanılmıştır. Çalışmanın evrenini, 2019-2020 Ĕ̆̈itim Öğretim yılında Elazı̆̆ il merkezindeki resmi okullarda görev yapan öğretmenler oluşturmaktadır. Araştırmanın örneklemi kota örnekleme yöntemiyle belirlenmiş olup, araştırma çeşitli kademelerde görev yapan 436 öğretmenden alınan verilerin analizi yapılarak gerçekleştirilmiştir. Araştırma kapsamında veriler, Örgütsel Adalet Ölçeği (ÖAÖ), Otantik Liderlik Ölçeği (OLÖ), Örgütsel Mutluluk Ölçeği (ÖMÖ) ve araştırmact tarafindan hazırlanan kişisel bilgi formu ile toplanmıştır. Elde edilen veriler, güvenirlik, yüzde, frekanslar, $t$-testi, Pearson Korelasyon analizi ve Çoklu Regresyon Analizine tutulmuştur. Araştırmadan elde edilen bulgulara göre, öğretmenlerin örgütsel adalet, otantik liderlik ve örgütsel mutluluk puanlarl, cinsiyet ve medeni durum değişkenleri açısından anlamlı düzeyde farklllaşmamaktadır. Katılımcıların örgütsel adalet ve otantik liderlik algıları ile örgütsel mutluluk düzeyleri arasında pozitif yönde anlamlı ilişkiler vardır. Katılımcıların örgütsel adalet ve otantik liderlik (ilişkilerde şeffaflık alt boyutu) algıları örgütsel mutluluk düzeylerini anlamlı şekilde yordamakta ve bu iki değişken örgütsel mutluluktaki toplam değişimin yaklaşık \%18'ini açıklamaktadır. Bu bulgulara göre öğretmenlerin örgütsel mutluluk düzeylerinde örgütsel adaletin ve otantik liderlik davranışlarının rolü olduğu söylenebilir.
\end{abstract}

Anahtar Kelimeler: Örgütsel adalet, otantik liderlik, örgütsel mutluluk, öğretmen 


\section{Introduction}

Organizations are one of the major environments where people have the most intensive relationship with individuals. In order to achieve the goals of the organization, the feelings, thoughts, attitudes and perceptions of its employees are highly important. These feelings and perceptions of employees also determine their satisfaction with the organization. Employees want an emotionally pleasant, beautiful and happy environment in the organizations in which they work. It can be suggested that the personal characteristics of executives and employees are influenced by their behaviors. A person who is happy in the organization where he/she works can also affect the happiness of other employees by showing almost a domino effect. In this context, it is highlighted that the energy of executives and the emotions they radiate are significant in organizations (Alparslan, Yastioglu and Stone, 2019). According to Scott, being happy at work is one of the fundamental factors of satisfaction with life. Because the work that a person does is an integral part of his/her identity. Moreover, the professional roles that a person takes on in his/her professional life are an important factor in their self-worth and self-respect (Scott, 2008). Individual happiness can also affect the happiness of the organization consisting of individuals. Thus, the resulting state of happiness in the organization is defined as organizational happiness (Moçoşoğlu and Kaya, 2018). Organizational happiness supports people to handle all kinds of problems, pressures and issues that may hinder their managerial or functional activities for realizing their goals and objectives. In this regard, organizational happiness shows the extent to which the goals of individual and organization are achieved together (Bulut, 2015). There are many factors that affect the happiness and satisfaction levels of individuals working in organizations. The existence of some factors that are thought to affect the happiness of teachers working in schools, which is an educational organization, is the starting point of this study. In the literature review conducted in this direction, organizational justice and perception of authentic leadership were identified as the factors that could affect teachers' happiness levels.

Organizational justice refers to level that individuals or groups perceive the attitudes and behaviours towards them in the organization to be fair (Balc1, 2020). Organizational justice deals with employee evaluations of whether the work and operations of the organizations in which they work are 
fair, and the impact of these evaluations on the organization (Moorman, 1991). It is noted that high perception of organizational justice in an organization is a sign that employers respect and trust their employees (Demirtaş and Kılıç, 2016). At the same time, it can be put forward that organizational justice has a number of effects on the productivity of the organization and on the individuals working in the organization. The leader has an important role to reveal these effects. Considering the importance of collecting accurate information to make a fair decision, it is known that monitoring the leader is essential for influencing an employee's perception of fair treatment. The fact that a leader takes steps to collect information about the performance of subordinates will lead to the idea that the distribution of rewards is fair. On the contrary, if the subordinate thinks that his/her executive has less knowledge about his/her job, he may have the idea that the distribution of rewards is unfair (Niehoff and Moorman, 1993). Therefore, it can be suggested that organizational justice has a number of effects on the productivity of the organization and on the individuals working in the organization. Individuals working in an organization expect leaders to behave fairly. Similarly, Yılmaz (2010) notes that people want to be treated fairly and equally. In this regard, organizational justice plays a significant role in teachers' fondness for their profession and occupation of the teaching profession an important place in their lives (Turhan, Erol, Demirkol, and Özdemir, 2019). Therefore, it was also included in this study to examine the perception of organizational justice as one of the variables that predicts teachers' happiness.

Leadership is defined as" the ability to influence the group to achieve goals or vision" (Robbins and Judge, 2017). Leadership has always been harder in troubled times. These tough environments that organizations face make it necessary to focus on what factors constitute real leadership. In life, new challenges are constantly emerging in organizations, and the leader must focus on overcoming these challenges in a short time, and restore trust, hope and optimism in the organization, anticipating the negative issues that may arise and flexing these difficult situations (Avolio and Gardner, 2005). Based on these considerations, it can be suggested that the leadership factor is of great importance in organizations, and that leadership is an effective factor to achieve the organization's goal. In this scope, another variable of this research is authentic leadership. The word authentic is an adjective that means "original, bearing the features that have existed for a very long time" 
(Turkish Language Association, 2020). At the core of authenticity is the fact that a person knows, recognizes, accepts himself/herself as he/she is, and can be honest with himself/herself (Kesken and Ayyıldız, 2008). In line with these clarifications, it is possible to say that the authentic leader is a leader who has leadership characteristics inherently, and knows his/her strengths and weaknesses, and who is at peace with himself/herself and is an honest leader inherently. Given that research on positive psychology has been conducted more frequently over the past quarter of a century, it is difficult to say that these studies are yet in adequate quantity. Therefore, it is believed that the study of positive leadership characteristics will contribute to the literature. Authentic leadership is one of the types of positive leadership, and it is thought that research on this topic will make significant contributions to the literature. As a result, the study of teachers' perceptions of authentic leadership was included in the study.

Organizational happiness is one of the indispensable elements that people working in organizations care about the most. A significant part of the lives of children, who are adults of the future, is spent at schools. Students interact with their teachers at schools more than their families and other adults around them. At this point, the duties and responsibilities of teachers are considered to be very important. It can be put forward that the high levels of organizational happiness in the organizations where teachers work while performing their profession will influence their performance and professional development processes. In this context, it is regarded significant to study teachers' organizational happiness.

It is considered important to study the relationship between teachers' perceptions of organizational justice and authentic leadership and their levels of organizational happiness. However, although there are studies that address teachers' perception of organizational justice, authentic leadership and organizational happiness separately, no research that examines the relationship between these three variables has been found. In this context, it is believed that this research will contribute to the literature and shed light on further researches.

The aim of this research is to examine the relationship between teachers' perceptions of organizational justice and authentic leadership and their levels of organizational happiness. Along with this general aim, it was tried to answer the following questions: 
1. Do teachers' perceptions of organizational justice, authentic leadership and organizational happiness differ by their gender and marital status?

2. Is there a significant relationship between teachers' perceptions of organizational justice and authentic leadership and their levels of organizational happiness?

3. Do teachers' perceptions of organizational justice and authentic leadership significantly predict their organizational happiness?

\section{Method}

\section{Model of research}

This study, which investigates the relationship between teachers' perceptions of organizational justice and authentic leadership and their levels of organizational happiness, adopts the survey model (Karasar 2010, p. 81). It is noted that researches conducted in the survey model are generally designed to describe an already-existing situation as it is. However, it is highlighted that it is possible, in the survey model, to gather the perceptions, attitudes, opinions and beliefs of individuals about any subject by means of appropriate measuring instruments, and to investigate the relationships between variables through proper statistical methods (Büyüköztürk, Çakmak, Akgün, Karadeniz, and Demirel, 2010, p.231-232; Toker-Gokce, 2018, p.240).

\section{Population and Sample}

The population of this research consists of the teachers working at four different education levels including official kindergarten, primary school, secondary school and high school, in the city centre of Elazig in the 2019-2020 academic year. The quota sampling method was used to select the sample. In the quota sampling method, the mass to be investigated is divided into parts by taking into account certain selection criteria, and samples are taken from these parts, and the quotas to be taken from these groups are determined, and hence the research is conducted accordingly (Küçük, 2016, p. 98). Aziz (2015, pp.54-55) highlights that in the quota sampling method, the researcher must take samples until reaching the number of members representing each group, and it is important to pay attention to determining these people as objectively 
as possible. Numerical information about other demographic characteristics of participants is presented in Table 1 .

Table 1.Demographic Characteristics of Participants

\begin{tabular}{llll}
\hline $\begin{array}{l}\text { Demographic } \\
\text { Variable }\end{array}$ & Groups & (n) & $(\%)$ \\
\hline Gender & Female & 256 & 58.7 \\
\cline { 2 - 4 } & Male & 180 & 41.3 \\
\cline { 2 - 4 } & Total & 436 & 100 \\
\hline \multirow{2}{*}{ Marital status } & Married & 361 & 82.8 \\
\cline { 2 - 4 } & Single & 75 & 17.2 \\
\cline { 2 - 4 } & Total & 436 & 100 \\
\hline Training Level & kindergarten & 81 & 18.6 \\
\cline { 2 - 4 } & primary school & 129 & 29.6 \\
\cline { 2 - 4 } & secondary school & 98 & 22.5 \\
\cline { 2 - 4 } & high school & 128 & 29.4 \\
\cline { 2 - 4 } & Total & 436 & 100 \\
\hline Branş & pre-school teachers & 97 & 22.2 \\
\cline { 2 - 4 } & primary-school teachers & 106 & 24.3 \\
\cline { 2 - 4 } & social-sciences teachers & 77 & 17.7 \\
\cline { 2 - 4 } & science teachers & 50 & 11.5 \\
\cline { 2 - 4 } & sports/fine arts/other branch teachers & 106 & 24.3 \\
\cline { 2 - 4 } & Total & 436 & 100 \\
\hline
\end{tabular}

Considering Table 1, 58.7\% of 436 teachers participating in the study are female and $41.3 \%$ are male. $82.8 \%$ of teachers are married and $17.2 \%$ are single. $18.6 \%$ of the teachers work at kindergarten, $29 \%$ at primary school, $22.5 \%$ at secondary school and $29.4 \%$ at high school. In terms of branches, $22.2 \%$ of the teachers are pre-school teachers, $24.3 \%$ of them are primary-school teachers, and $17.7 \%$ social-sciences teachers, $11.5 \%$ science teachers and $14.3 \%$ sports/fine arts/other branch teachers.

\section{Data Collection Tools}

In this study, as the fundamental data collection tools, the Authentic Leadership Questionnaire (ALQ), Organizational Justice Index (OJI), and Organizational Happiness Scale (WBWS) as well as the Personal Information Form (PIF) prepared by the researcher to identify the demographic characteristics of the participants were used. The Personal Information Form consists of the items on the types of schools the participants work, their branches, and their seniority status, etc. 
The Organizational Justice Index (OJI), developed by Hoy and Tarter (2004), was adapted to the Turkish language by Taştan and Yllmaz (2008). The index consists of a single factor and 10 items, as in the original form. Some of the items in the scale include: "There is no privileged treatment at this school. The principal adheres to high ethical standards. Teachers agree with the decisions that affect them". It was determined in the Explanatory Factor Analysis (EFA) that it consists of a single factor. It was seen, in the studies for adaptation of the scale to the Turkish language, that the factor loads of the scale varied between .44 and .89 , and this one-dimensional structure accounts for around $62 \%$ of the total variance. OJI, which is originally a 7 likert-type index, was adapted to the Turkish language as a 5 likert-type index. The scores that can be obtained from the index range between 10-50. High scores obtained from the index indicate a high perception of organizational justice at school. The Cronbach Alpha internal consistency coefficient of the index was calculated as 92 for the whole scale.

The Authentic Leadership Questionnaire (ALQ) was developed by Walumbwa, Avolio, Gardner, Wernsing and Peterson (2008) and adapted to the Turkish language by Tabak, Polat, Coşar and Türköz (2012). The questionnaire consists of 16 items, and it is designed as a 5 likert-type scale, as in its original version. The dimensions of ALQ are called as "relational transparency (5 items)", "internalized moral perspective (4 items)", "balanced processing (3 items)" and "self-awareness (4 items). The sample items regarding the dimension of relational transparency are the following: "He/she clearly says what he/she wants to say. The feelings he/she reveals are exactly the same as what he/she feels". The sample items regarding the dimension of internalized moral perspective are the following: "What my leader does is consistent with what he/she believes. He/she makes his/her decisions according to his/her value judgments". The sample items regarding the dimension of balanced processing are the following: "He/she examines the relevant information thoroughly before making a decision. He/she listens carefully to different opinions before reaching a conclusion". The sample items regarding the dimension of selfawareness are the following: "He/she knows how his/her abilities are evaluated by others. He/she knows when to reassess his/her attitude on important issues". In the Confirmatory Factor Analysis (CFA), it was found that the fit index values of this four-factor structure were within acceptable limits 
$(\chi 2 / \mathrm{sd}=2.53, \mathrm{GFI}=.92, \mathrm{RMSEA}=.06, \mathrm{IFI}=.95)$. The Cronbach Alpha internal consistency coefficient of the questionnaire was calculated as .86 for the dimension of relational transparency, .83 for the dimension of internalized moral perspective, .85 for the dimension of balanced processing, .90 for the dimension of self-awareness and .93 for the whole questionnaire.

Organizational happiness Scale (WBWS) was developed by Demo and Paschoal (2013) and adapted to the Turkish language by Arslan and Polat (2017). Adaptation studies of the scale were carried out with the data obtained from 242 teacher participants. WBWS consists of 3 sub-dimensions and 29 items. It was found in CFA that the fit index values of this three-factor structure were within acceptable limits $(\chi 2 / \mathrm{sd}=3.95, \mathrm{CFI}=.97$, RMSEA=.09,

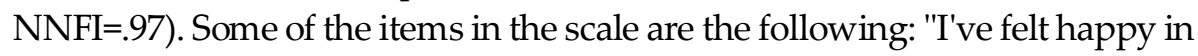
my job for the last six months. I've felt peaceful in my job for the last six months. I've been using my potential in my job. I've been progressing in my job in line with the goals I've set for my life". It was seen that the item factor loads of the scale varied between .51 and .85 . The sub-dimensions of the scale cannot be scored separately and the scale is assessed over the total score. WBWS is designed as a 5 likert-type scale. High scores obtained from the scale indicate a high level of organizational happiness. The Cronbach Alpha internal consistency coefficient of the scale was calculated as .96 for the whole scale.

\section{Collection of Data and Permissions}

Before collection of data, the ethical permission from Firat University Social and Human Sciences Research Ethics Committee (Number: 97132852/302.14.01), and then the application permission from the Elazig Directorate of National Education (Number: 79137285-605.01-E.21858305) were obtained. After the necessary permissions were obtained, the researcher went to the schools, and the forms containing the measurement tools were applied to the teachers who stated that they were willing to participate in the research.

\section{Data Analysis}

Before the analyses to be carried out in this study were determined, it was examined, by looking at the skewness and kurtosis values, whether the collected data showed normal distribution. It is seen that the coefficients of 
skewness vary between -.847 and -.625, while the coefficients of kurtosis vary between .265 and .906 . According to these results, it is possible to suggest that the data shows normal distribution (Can, 2013, p. 85; Özdemir, 2018, p. 143). Therefore, it was decided to use parametric tests in the research. $t$ test was conducted in order to find whether there was a significant difference between binary groups in the study, while the relationships between variables were examined using Pearson correlation analysis. Finally, the predictability of organizational justice and authentic leadership variables on organizational happiness was studied by performing multiple regression analysis.

\section{Findings}

This part presents the findings obtained from the research. In this context, the findings were reached by analysing the data, obtained from the teachers participating in the study, through $t$ test, Pearson correlation analysis and multiple regression analysis.

\section{Findings Regarding the Variable of Gender}

It was examined, by $t$ test, whether the teachers' perceptions of organizational justice and authentic leadership and their levels of organizational happiness differed significantly by their gender, and the findings are presented in Table 2 .

Table 2. Findings of t Test on Whether the Teachers' Perceptions of Organizational Justice and Authentic Leadership and Their Levels of Organizational happiness Differed Significantly by Their Gender

\begin{tabular}{lllllll}
\hline variables & gender & $\mathrm{n}$ & $\overline{\mathrm{x}}$ & $\mathrm{SD}$ & $\mathrm{t}$ & $\mathrm{p}$ \\
\hline \multirow{2}{*}{ Organizational Justice } & Female & 256 & 39.78 & 7.65 & -1.671 & .095 \\
\cline { 2 - 7 } Authentic Leadership & Male & 180 & 40.97 & 6.84 & & \\
\hline \multirow{2}{*}{ 1.relational transparency } & Female & 256 & 62.81 & 10.82 & -1.020 & .308 \\
\cline { 2 - 7 } & Male & 180 & 63.86 & 10.07 & & .605 \\
\hline \multirow{2}{*}{ 2.internalized moral perspective } & Female & 256 & 20.00 & 3.61 & -.518 & \\
\cline { 2 - 7 } & Male & 180 & 20.18 & 3.59 & & .151 \\
\hline \multirow{2}{*}{ 3.balanced processing } & Female & 256 & 15.72 & 2.99 & -1.440 & .282 \\
\hline \multirow{2}{*}{ 4.self-awareness } & Male & 180 & 16.13 & 2.75 & & \\
\hline \multirow{2}{*}{ Organizational Happiness } & Female & 256 & 11.34 & 2.40 & -1.087 & .463 \\
\cline { 2 - 7 } & Male & 180 & 11.58 & 2.21 & & .735 \\
\hline
\end{tabular}


Considering the table in terms of organizational justice score, it was discovered that the organizational justice perceptions of the participants did not differ significantly by their gender ( $t=-1.671 ; \mathrm{p}=.095, \mathrm{p}>.05)$. This finding shows that there are no statistically significant differences between teachers' perceptions of authentic leadership and their gender.

It was determined that the participants' total scores of authentic leadership $(t=1.020 ; p=.308, p>.05)$, scores of relational transparency dimension $(t=-.518$; $\mathrm{p}=.605, \mathrm{p}>.05)$, scores of internalized moral perspective dimension $(\mathrm{t}=-1.440$; $\mathrm{p}=.151, \mathrm{p}>.05)$, scores of balanced processing dimension $(\mathrm{t}=-1.077 ; \mathrm{p}=.282$, $\mathrm{p}>$.05), and scores of self-awareness dimension ( $\mathrm{t}=-.735 ; \mathrm{p}=.463, \mathrm{p}>.05)$ didn't differ significantly by their gender. This finding indicates that there are no statistically significant differences, by gender, in the teachers' total score of authentic leadership and scores of all dimensions of authentic leadership.

Considering the participants' scores of organizational happiness in terms of their gender, no significant differentiation was found ( $t=.468 ; \mathrm{p}=.640 \mathrm{p}>.05$ ). According to this finding, the teachers' levels of organizational happiness did not differ by their gender.

\section{Findings Regarding the Variable of Marital Status}

It was examined, by t test, whether the teachers' perceptions of organizational justice and authentic leadership and their levels of organizational happiness differed significantly by their marital status, and the findings are presented in Table 3.

Table 3.Findings oft Test on Whether the Teachers' Perceptions of Organizational Justice and Authentic Leadership and Their Levels of Organizational happiness Differed Significantly by Their Marital Status

\begin{tabular}{lllllll}
\hline \multirow{2}{*}{ Variables } & $\begin{array}{l}\text { Marital } \\
\text { Status }\end{array}$ & $\mathrm{n}$ & $x^{-}$ & $\mathrm{SD}$ & $t$ & $\mathrm{p}$ \\
\hline \multirow{2}{*}{ Organizational Justice } & Married & 361 & 40.24 & 7.48 & -.216 & .829 \\
\cline { 2 - 7 } & Single & 75 & 40.44 & 6.70 & & \\
\hline \multirow{2}{*}{ Authentic Leadership } & Married & 361 & 63.31 & 10.75 & .280 & .780 \\
\cline { 2 - 7 } 1.relational transparency & Single & 75 & 62.93 & 9.39 & & .760 \\
\hline \multirow{2}{*}{ 2.internalized moral perspective } & Married & 361 & 20.05 & 3.71 & -.305 & .735 \\
\cline { 2 - 7 } & Single & 75 & 20.19 & 3.03 & & .339 \\
\hline \multirow{2}{*}{ 3.balanced processing } & Married & 361 & 15.91 & 2.97 & & \\
\cline { 2 - 7 } & Single & 75 & 15.79 & 2.53 & & \\
\hline
\end{tabular}




\begin{tabular}{lllllll}
\hline \multirow{2}{*}{4. self-awareness } & Married & 361 & 15.85 & 3.06 & .171 & .865 \\
\cline { 2 - 7 } & Single & 75 & 15.79 & 3.16 & & \\
\hline \multirow{2}{*}{ Organizational Happiness } & Married & 361 & 115.98 & 15.79 & -.997 & .319 \\
\cline { 2 - 7 } & Single & 75 & 117.95 & 14.38 & & \\
\hline $\mathrm{N}=436$ & & & & & & \\
\hline
\end{tabular}

Considering the table, it was discovered that the organizational justice perceptions of the participants did not differ significantly by their marital status $(t=-216 ; \mathrm{p}=.829, \mathrm{p}>.05)$. According to this finding, there is no statistically significant differentiation between teachers' perceptions of organizational justice and their marital status.

Considering the perception of authentic leadership, it was determined that there was no significant difference in the total score of authentic leader$\operatorname{ship}(t=.280 ; \mathrm{p}=.780, \mathrm{p}>.05)$, its relational transparency dimension $(t=-.305 ; \mathrm{p}=.760$, $\mathrm{p}>.05)$, its internalized moral perspective dimension ( $t=.339 ; \mathrm{p}=.735, \mathrm{p}>.05)$, its balanced processing dimension ( $t=1.093 ; \mathrm{p}=.275, \mathrm{p}>.05)$ and its self-awareness dimension ( $t=.171 ; \mathrm{p}=.865, \mathrm{p}>.05)$. This finding indicates that there are no statistically significant differences, by marital status, in the teachers' total score of authentic leadership and scores of all dimensions of authentic leadership.

Considering the organizational happiness, no statistically significant differentiation was revealed ( $t=.997 ; \mathrm{p}=.319, \mathrm{p}>.05)$. According to this finding, it can be suggested that there is no statistically significant differentiation between the teachers' perception of organizational happiness and their marital status.

\section{Findings Regarding the Relationship between the Variables}

The relationships between the teachers' perceptions of organizational justice and authentic leadership and their levels of organizational happiness were examined by Pearson Correlation Analysis, and the findings are presented in Table 4 . 
Table 4. Findings of Pearson Correlation Analysis on Examination of Relationships between the Teachers' Perceptions of Organizational Justice and Authentic Leadership and Their Levels of Organizational happiness

\begin{tabular}{|c|c|c|c|c|c|c|c|}
\hline & (1) & $(2)$ & (3) & (4) & (5) & (6) & $(7)$ \\
\hline (1) Organizational Happiness & 1 & & & & & & \\
\hline (2) Organizational Justice & $.383^{* *}$ & 1 & & & & & \\
\hline (3) Authentic Leadership & $.382^{* *}$ & $.719^{* *}$ & 1 & & & & \\
\hline (4) (relational transparency) & $.372^{* *}$ & $.653^{* *}$ & $.903^{* *}$ & 1 & & & \\
\hline (5) (internalized moral perspective) & $.295^{* *}$ & $.611^{* *}$ & $.869^{* *}$ & $.711^{* *}$ & 1 & & \\
\hline (6) (balanced processing) & $.310^{* *}$ & $.578^{* *}$ & $.845^{* *}$ & $.658^{* *}$ & $.664^{* *}$ & 1 & \\
\hline (7) (self-awareness) & $.357^{* *}$ & $.682^{* *}$ & $.905^{* *}$ & $.752^{* *}$ & $.698^{* *}$ & $.740^{* *}$ & 1 \\
\hline${ }^{* *} \mathrm{p}<.01, \mathrm{~N}=436$ & & & & & & & \\
\hline
\end{tabular}

When Table 4 is examined, it is seen that there are positive significant relationships between teachers' organizational happiness, and organizational justice at moderate degree $(\mathrm{r}=.383 ; \mathrm{p}<.01)$, and the total score of authentic leadership at moderate degree $(\mathrm{r}=.382 ; \mathrm{p}<.01)$, and relational transparency dimension at moderate degree $(\mathrm{r}=.372 ; \mathrm{p}<.01)$, and internalized moral perspective at high degree $(\mathrm{r}=.295 ; \mathrm{p}<.01)$, and balanced processing dimension at high degree $(\mathrm{r}=.310$; $\mathrm{p}<.01)$, and self-awareness dimension at moderate degree $(\mathrm{r}=.357 ; \mathrm{p}<.01)$. According to this finding of the study, it can be put forward that as teachers' perceptions of organizational justice and authentic leadership increase, their levels of organizational happiness increase. Namely, as teachers' perceptions of organizational justice and authentic leadership decrease, their levels of organizational happiness decrease.

Secondly, it is seen in the table that there are positive significant relationships between teachers' perceptions of organizational justice, and the total score of authentic leadership at high degree $(\mathrm{r}=.719 ; \mathrm{p}<.01)$, and relational transparency dimension at moderate degree $(\mathrm{r}=.653 ; \mathrm{p}<.01)$, and internalized moral perspective at moderate degree $(\mathrm{r}=.611 ; \mathrm{p}<.01)$, and balanced processing dimension at moderate degree $(\mathrm{r}=.578 ; \mathrm{p}<.01)$, and self-awareness dimension at moderate degree $(\mathrm{r}=.682 ; \mathrm{p}<.01)$. According to this finding of the study, it can be suggested that as teachers' perceptions of organizational justice increase, their authentic leadership perceptions (in total scores and all sub-dimensions) increase. Namely, it can be put forward that as teachers' perceptions of organizational justice decrease, their authentic leadership perceptions (in total scores and in all sub-dimensions) will also decrease. 


\section{Findings Regarding Prediction of Organizational Happiness}

A multiple regression analysis was performed on how teachers' perceptions of organizational justice and authentic leadership predict their levels of organizational happiness, and the findings are presented in Table 5.

Table 5.Findings of Multiple Regression Analysis on How Teachers' Perceptions of Organizational Justice and Authentic Leadership Predict Their Levels of Organizational Happiness

\begin{tabular}{lllllll}
\hline $\begin{array}{l}\text { Predicted } \\
\text { Variable }\end{array}$ & Predictive Variables & $\mathrm{B}$ & $\begin{array}{l}\text { Standart } \\
\text { Error }\end{array}$ & $\mathrm{B}$ & $\mathrm{t}$ & $\mathrm{p}$ \\
\hline $\begin{array}{l}\text { Organiza- } \\
\text { tional }\end{array}$ & Constant & 76.880 & 4.348 & & 17.683 & .000 \\
\cline { 2 - 7 } Happiness & Organizational Justice & .466 & .134 & .220 & 3.467 & $.001^{* *}$ \\
\cline { 2 - 7 } & relational transparency & .756 & .321 & .175 & 2.352 & $.019^{*}$ \\
\cline { 2 - 7 } & internalized moral perspective & -.236 & .372 & -.044 & -.635 & .526 \\
\cline { 2 - 7 } & balanced processing & .269 & .461 & .040 & .582 & .561 \\
\cline { 2 - 7 } & self-awareness & .389 & .411 & .077 & .947 & .344 \\
\hline $\mathrm{R}=.420, \mathrm{R}^{2}=.176$, \\
Adjusted $\Delta \mathrm{R}^{2}=.167, \mathrm{~F}(5,430)=18.409, \mathrm{p}=000,{ }^{* *} \mathrm{p}<.01$ & & & & & \\
\hline
\end{tabular}

When Table 5 is examined, it is seen that the organizational justice perception and the dimensions of authentic leadership, e.g. relational transparency, internalized moral perspective, balanced processing and self-awareness significantly predict teachers' organizational happiness $\left(\mathrm{R}=.420, \mathrm{R}^{2}=.176, \mathrm{~F}(5,430)=18.409\right.$, $\mathrm{p}=000, \mathrm{p}<.01)$. Considering $t$ values for regression coefficients, it is revealed that organizational justice and dimension of relational transparency of authentic leadership predict the organizational happiness at a statistically significant level. It is evident that other three dimensions of authentic leadership (e.g. internalized moral perspective, balanced processing and self-awareness) do not predict the organizational happiness at a significant level. Based on this result, it can be suggested that organizational justice and relational transparency account for around $18 \%$ of the total variance in the organizational happiness.

\section{Discussion, Results and Recommendations}

The research firstly investigated the teachers' perceptions of organizational justice and authentic leadership and their levels of organizational happiness by the variable of gender. According to the results obtained from the study, it was concluded that teachers' perceptions of organizational justice and authentic leadership and their levels of organizational happiness did not differ 
significantly by their gender. This result suggests that the female and male teachers' perceptions of organizational justice and authentic leadership and their levels of organizational happiness are close to each other. There are studies in the literature that show similarities and differences with this result of the research. For example, the study performed by Cömert, Demirtaş, Üstüner, and Özer (2008) with teachers working at high schools in Malatya revealed that teachers' perceptions of organizational justice did not differ according to their gender. In the study carried out by Korkut (2019) with primary school teachers working in Malatya, it was discovered that teachers' perceptions of organizational justice and organizational happiness did not differ by their gender. Similarly, the study, conducted by Toplu (2010) with employees in an organization, found that the employees' perceptions of organizational justice did not differ significantly by their gender. These results support the results of this research. On the other hand, Demirbilek (2018) and Yoldaş (2018) report in their study that male teachers' perceptions of organizational justice are higher than those of women. Polat and Celep (2008), in their study with teachers working in vocational and technical high schools, evaluated the leadership of male teachers as fairer than that of female teachers. The study by Cesur (2019) found that female teachers' perceptions of organizational justice were higher than those of male teachers. The results of this study that the perception of organizational justice does not differ by gender show similarities with some studies and differences from some in the literature. According to this result, it can be suggested that gender is not a determining factor in teachers' perceptions of organizational justice.

In this study, it was concluded that teachers' perceptions of authentic leadership were not significantly differentiated by their gender when examined in terms of total score and sub-dimensions. In the study conducted by Yaraş (2017) with classroom teachers working at primary schools, it was found that the authentic leadership perceptions of the participants did not differ by their gender, both in terms of total scores and sub-dimensions. As a result of the research performed by Koçak (2019) with teachers working at various levels in Siirt province, it was found that participants' perceptions of authentic leadership were not significantly differentiated in terms of their gender. The research conducted by Başaran (2018) with teachers discovered that there was no significant differentiation by gender in the internalized moral perspective dimension of the authentic leadership. These results are similar to the results 
of this research. The fact that organizational justice and authentic leadership are not perceived differently by the gender of teachers can be explained by school administrators' avoidance of exhibiting attitudes towards the gender variable of teachers. Namely, it can be interpreted in the way that school administrators are not focused on the variable of gender in their attitudes towards male and female teachers.

The results of the studies, which were performed by Brouskeli, Kaltsi, and Loumakou (2018), Çetin (2019), Gürbüz (2020), Kotaoğlu (2019), Uğur (2019) and Korkut (2019) with teachers and revealed that teachers' levels of organizational happiness did not differ by their gender, are similar to the results of this research. On the other hand, the study, conducted by Düzgün (2016) with secondary school teachers, found that the male teachers' levels of organizational happiness were significantly higher than those of female teachers. Similarly, Sharma's (2012) study concluded that male teachers are happier than female teachers. On the other side, the study, carried out by Köse (2020) with teachers working at primary and high schools, determined that female teachers had higher levels of organizational happiness than male teachers. When the results are assessed together, it can be said that the organizational happiness is not clear in terms of gender. The concept of organizational happiness is a subject of research that has started to be addressed recently and the studies in this field are relatively limited, which makes it difficult to assess the organizational happiness in terms of gender. In Turkey, the parameters that may be influential on teachers' organizational happiness may be created by the variables other than gender.

The research secondly investigated the teachers' perceptions of organizational justice and authentic leadership and their levels of organizational happiness by the variable of marital status. As a result of the research, it was concluded that there was no significant differentiation between these variables and marital status. This conclusion on organizational justice corresponds to the result of Yoldaş's research (2018). On the other hand, the study by Korkut (2019) found that married teachers' perceptions of organizational justice were significantly higher than those of single teachers.

This study reached the result that the authentic leadership perceptions of the participants did not differ based on whether the teachers were married or single. Considering the literature, it was seen that similar results were reached by the study conducted by Koçak (2019) with teachers. The results of 
Başaran's research (2018) that there is no significant difference in both the total score and sub-dimensions of authentic leadership by marital status support the results of this study. Accordingly, it can be suggested that marital status is not a determining factor in teachers' perceptions of authentic leadership of school administrators.

The studies performed by Uğur (2019) and Düzü (2016) determined that teachers' levels of organizational happiness did not differ by their marital status. This finding supports the result of the present research. On the other side, the study by Korkut (2019) concluded that the married teachers' levels of organizational happiness were significantly higher than that of single teachers. Based on this result, it can be said that the marital status of teachers is not a determining factor in their organizational happiness.

The research thirdly investigated the relationships between teachers' perceptions of organizational justice and authentic leadership and their levels of organizational happiness. As a result of the research, it was found that there were positive relationships between the participants' levels of organizational happiness and their perceptions of organizational justice and authentic leadership (total score and all sub-dimensions). The fact that the studies conducted by Çetin (2019) and Korkut (2019) found positive relationships between teachers' perception of organizational justice and their levels of organizational happiness corresponds to the results of this study. Researchers highlight that there are positive relationships between the perception of organizational justice and employee happiness (Jandaghi, Alimadadi, Fard, and Golverdi, 2012), and negative relationships between organizational happiness and professional burnout (Reza and Leyli, 2016). In addition, as a result of the research, it was found that there were positive relationships between teachers' perceptions of organizational justice and authentic leadership (total score and all sub-dimensions). A study conducted with healthcare professionals in South Korea found a positive correlation between participants' perceptions of organizational justice and authentic leadership (Song and Seomun, 2014). In a study conducted with teachers in Brazil, it was revealed that teachers' perceptions of authentic leadership was a variable that has a positive impact on their perceptions of organizational justice (Alinezhad, Abbasian, and Behrangi, 2015). The present study found moderate and high-degree positive relationships between teachers' perceptions of organizational justice and authentic leadership and their levels of organizational happiness. 
Accordingly, as the teachers' perception of organizational justice increases, their perception of authentic leadership and level of organizational happiness increase. Namely, as the teachers' perception of organizational justice decreases, their perception of authentic leadership and level of organizational happiness decrease.

The research finally investigated how the teachers' perceptions of organizational justice and authentic leadership predict their levels of organizational happiness. The research reached the result that the organizational justice perception and the relational transparency dimension of authentic leadership predicted the organizational happiness significantly and positively. Çetin's study (2019) reports that organizational justice among teachers positively predicts the organizational happiness. Teachers' high perception of authentic leadership is a factor that has a positive impact on motivation and job satisfaction (Kılıç, 2019). A different study concluded that organizational justice positively affected teachers' organizational happiness (Korkut, 2019). As a matter of fact, it is highlighted that when individuals have a positive perception of justice for the organization where they work, they will be happier, because they will produce relatively more successful, productive and qualified products (Karademir and Çoban, 2010). The high level of organizational justice perceived by teachers has a positive impact on their quality of work life (Akar, 2017). It is noted that the increasing the level of organizational happiness contributes to the individuals' preparing themselves for development, to improving their tendency to follow the rules of the organization, and to developing their skills and acting in harmony with other employees (Azar and Bahrami, 2019). In this context, the fact that teachers feel happy at the schools where they work can have positive reflections in terms of their personal performance and professional output. Actually, it is emphasized that teachers who are happy at the schools where they work have high organizational commitment (Uzun and Kesicioğlu, 2019).

In line with the results obtained from this research, the following recommendations are made to researchers and practitioners:

- This study reveals that authentic leadership characteristics is a factor affecting teachers' organizational happiness. In this context, the leadership competencies of executive candidates can also be taken into account.

- This study determined a positive relationship between authentic leadership characteristics and teachers' levels of organizational happiness. In 
order to contribute to increasing the teachers' organizational happiness, executives can be given trainings on the importance of authentic leadership characteristics.

This study reveals that organizational justice is positively related to teachers' organizational happiness, and it is a factor that affects it. Based on this finding, in-service trainings can be given to improve executives' awareness of organizational justice.

\section{Kaynakça / References}

Alinezhad, M., Abbasian, H., and Behrangi, M. R. (2015). Investigating the effects of authentic leadership of managers on organizational commitment of teachers with organizational justice as the mediator variable. Ciência e Natura, 37, 407416.

Alparslan, A. M., Yastığlu, S. and Taş, M. A. (2019). Happy managers. Ankara: Nobel Scientific Works

Arslan, Y., and Polat, S. (2017). Adaptation of the organizational happiness scale to Turkish. Educational Administration: Theory and Practice, 23(4), 603-622.

Avolio, B. J., Luthans, F., and Walumba, F. O. (2004). Authenticleadership: Theory building for veritable sustained performance. Working paper: Gallup Leadership Institute, University of Nebraska-Lincoln.

Azar, M., and Bahrami, R. (2019). An investigation of organizational happiness impact on the working life quality; (Case study: Isfahan University's Staff). International Journal of Advanced Studies in Humanities and Social Science, 8(3), 255-265.

Aziz, A. (2015). Research methods and techniques in social sciences. (10th Edition). Ankara: Nobel Academy.

Balc1, A. (2020). Annotated glossary of educational management terms. Ankara: Pegem Academy (5th Edition).

Başaran, R. (2018). The relationship between authentic leadership and work commitment in secondary schools. Unpublished Master's Thesis, Aydin Adnan Menders University Institute of Social Sciences, Aydın.

Brouskeli, V., Kaltsi, V., and Loumakou, M. (2018). Resilience and occupational wellbeing of secondary education teachers in Greece. Issues in Educational Research, $28(1), 43-60$.

Bulut, A. (2015). Investigation of secondary school teachers' perceptions of organizational happiness: A norm study. Published Doctoral Thesis, Gaziantep University Institute of Educational Sciences, Gaziantep. 
Büyüköztürk, Ş., Çakmak, E. K., Akgün, Ö. E., Karadeniz, Ş., and Demirel, F. (2010). Scientific research methods. (5. Bakı). Ankara: Pegem Academy.

Can, A. (2013). Quantitative data analysis with SPSS. Ankara: Pegem Academy.

Cesur, A. (2019). Relationship between nepotism and organizational justice in school administration: The case of Afyonkarahisar. Unpublished Master's Thesis, Kütahya Dumlupınar University Institute of Educational Sciences, Kütahya.

Cömert, M., Demirtaş, H., Üstüner, M., and Özer, N. (2008). High school teachers' perceptions of organizational justice. Educational Sciences and Application, 7(13), 322.

Çetin, S. (2019). The relationship between secondary school teachers' organizational justice perception levels and organizational happiness levels. Unpublished Master's Thesis, Kocaeli University Institute of Social Sciences, Kocaeli

Demirbilek, N. (2018). The effect of client-oriented behaviors of school principals on teachers' perceptions of organizational justice and trust in principals. Unpublished Doctoral Thesis. İnönü University Institute of Educational Sciences, Malatya.

Demirtaş, Z. and Kılıç, Y. (2016). The relationship levels between high school teachers' perceptions of organizational justice and job satisfaction. Dicle University Journal of Ziya Gökalp Education Faculty,28, 259-267. doi: 10.14582/DUZGEF.727

Demo, G., and Paschoal, T. (2013). Well-Being at work scale: Exploratory and confirmatory validation in the United States comprising affective and cognitive components. Proceeding XXXVII Encontro da ANPAD, 7-11 September 2013. Rio de Janeiro.

Düzgün, O. (2016). The relationship between the happiness levels of the teachers working in secondary school and their classroom management skills. Unpublished Master's Thesis, Gaziosmanpaşa University Institute of Educational Sciences, Tokat.

Gürbüz, G. (2020). The relationship between teachers' organizational happiness perceptions and organizational trust levels. Unpublished Master's Thesis, Bahçeşehir University Institute of Educational Sciences, İstanbul.

Hoy, W. K. and Tarter, C. J. (2004). Organizational justice in schools: Nojustice without trust. International Journal of Educational Management, 18(4), 250-259. Doi: 10.1108/09513540410538831.

Jandaghi, G., Alimadadi, A., Fard, S. M. H., and Golverdi, M. (2012). Relationship between organizational justice and staff happiness in the institutes of standard and industrial research of Qom province and jihad agricultural management in Qom city. Human Resource Management, 43, 6618-6626.

Karasar, N. (2010). Scientific research method. (21st Edition). Ankara: Nobel Publication Distribution 
Kesken, J., and Ayyildiz, N. A. (2008). New perspectives in leadership approaches: Positive and authentic leadership. Ege Academic Overview 8(2), 729-754.

Koçak, O. (2019). The relationship between school administrators 'authentic leadership behaviors and teachers' organizational citizenship behaviors and organizational commitment levels. Unpublished Doctoral Thesis, Frrat University Institute of Educational Sciences, Elazig.

Korkut, A. (2019). Analysis of teachers' perceptions of organizational happiness, organizational cynicism and organizational justice. Unpublished Doctorate Thesis, İnönü University Institute of Educational Sciences, Malatya.

Kotaoğlu, Z. (2019). The relationship between the trust of teachers working in primary education institutions in their administrators and organizational happiness levels. Unpublished Master's Thesis, Sakarya University Institute of Educational Sciences, Sakarya.

Köse, Ö. (2020). Investigation of the relationship between school DNA profiles and organizational happiness levels according to teachers' perceptions. Unpublished Master's Thesis, Recep Tayyip Erdogan University Institute of Social Sciences, Rize.

Küçük, O. (2016). Scientific research methods. Bursa: Ekin Publishing House.

Moçoşoğlu, B., and Kaya, A. (2018). The relationship between organizational silence and organizational happiness levels of school administrators and teachers: The case of Şanluurfa. Harran Education Journal, 3(1), 52-70.

Moorman, R. H. (1991). Relationship between organizational justice and organizational citizenship behaviors: Do fairness perceptions influenceemployee citizenship? Journal of Applied Psychology, 76(6), 845-855.

Niehoff, B. P., and Moorman, R. H. (1993). Justice as a mediator of the relationship between methods of monitoring and organizational citizenship behavior. Academy of Management Journal, 36(3), 527-556.

Özdemir, M. (2018). Data analysis methods: Quantitative and qualitative data analysis. K. Beycioğlu, N.Özer and Y. Kondakçı (Editors), In Research in educational management (p.133-167). Ankara: Pegem Academy.

Polat, S., and Celep, C. (2008). Secondary school teachers' perceptions of organizational justice, organizational trust, organizational citizenship behaviors. Educational Administration: Theory and Practice, 14(2), 307-331.

Reza, A. H., and Leyli, B. E. (2016). Investigating the role of organizational happiness inteachers' occupational burnout. Journal of Fundamental and Applied Sciences, 8(2), 1444-1465.

Robbins, S. P., and Judge, T. A. (2017). Organizational behavior (Translation editor: İ. Erdem, translation from 14th edition). Ankara: Nobel Publishing House. 
Scott, D. E. (2008). Happiness at work. Tennessee Nurses Association. 26 May. 2019. https://www.thefreelibrary.com/Happiness+at+work.-a0191286519.

Sharma, A. (2012). Happiness of high school teachers: The role of school, gender and their interaction effect. Arts, Social Sciences, 1(2), 74-81.

Song, B., and Seomun, G. (2014). The influential factors related to organizational citizenship behavior of nurses: With focus on authentic leadership and organizational justice. Journal of Korean Academy of Nursing Administration, 20(2), 237-246.

Tabak, A., Polat, M., Coşar, S., and Türköz, T. (2012). Authentic leadership scale: Reliability and validity study. İSGÜÇ Industrial Relations and Human Resources Magazine, 14(4), 89-106.

Taştan, M., and Y1lmaz, K. (2008). Organizational citizenship and organizational justice scales' adaptation to Turkish. Education and Science, 33(150), 87-96.

Toker-Gökçe, A. (2018). Sampling methods and sampling process. In K.Beycioğlu, N. Özer and Y. Kondakçı (Editors), Research in educational management (p.239-268). Ankara: Pegem Academy.

Toplu, D. (2010). The effect of organizational justice on trust in managers and a research. Unpublished Master's Thesis, Istanbul University Institute of Social Sciences, Istanbul.

Turhan, M., Erol, Y. C., Demirkol, M., and Özdemir, T. Y. (2019). The relationship between organizational justice perception and job involvement in teachers. SDU International Journal of Educational Studies, 6(2), 161-173. doi:10.33710/sduijes.637366

Türk Dil Kurumu (TDK). (2020). Glossary of science and art terms. https://sozluk.gov.tr/.

Uğur, S. (2019). The relationship between the learning school and school happiness. Unpublished Master's Thesis, Van Yüzüncü Y1l University Institute of Educational Sciences, Van.

Uzun, T. and Kesicioglu, O.S. (2019). Examining the relationships between preschool teachers' organizational happiness, job satisfaction and organizational commitment. Mediterranean Journal of Educational Research, 13(29), 39-52. doi: 10.29329/mjer.2019.210.3

Walumbwa, F. O., Avolio, B. J., Gardner, W. L., Wernsing, T. S., and Peterson, S. J. (2008). Authentic leadership: Development and validation of a theory-based measure. Journal of Management, 34(1), 89-126.

Yaras, Z. (2017). The effect of authentic and holistic leadership styles of school administrators on positive organizational behavior: Application of artificial neural networks. Unpublished Doctorate Thesis, Furat University Institute of Educational Sciences, Elazı̆̆. 
Ylmaz, K. (2010). Organizational justice perceptions of teachers working in public secondary schools. Education in Theory and Practice, 10(1), 579-616.

Yoldas, A. (2018). Investigation of the effects of school administrators 'ethical leadership behaviors on teachers' perceptions of organizational justice. Unpublished Master's Thesis, Bahçeşehir University Institute of Educational Sciences, İstanbul.

\section{Kaynakça Bilgisi / Citation Information}

Zincirli, M. and Demir, H. (2021). The relationship between teachers' perceptions of organizational justice and authentic leadership and their levels of organizational happiness. OPUS-International Journal of Society Researches, 17(37), 3976-3998. DOI: 10.26466/opus. 877220 